\title{
B-Cell Lymphoma/Leukemia 11A
}

National Cancer Institute

\section{Source}

National Cancer Institute. B-Cell Lymphoma/Leukemia 11A. NCI Thesaurus. Code C97396.

B-cell lymphoma/leukemia 11A (835 aa, $\sim 91 \mathrm{kDa}$ ) is encoded by the human BCL11A gene.

This protein is involved in the regulation of both cell projection formation and lymphopoiesis. 